\title{
Effect of Machining the Load Capacity Notched Components
}

Michal Lattner, Frantisek Holesovsky

Faculty of Production Technology and Management, J. E. Purkyne University in Usti nad Labem. Pasteurova 3334/7, 400 01 Usti nad Labem. Czech Republic. E-mail: lattner@fvtm.ujep.cz, holesovsky@fvtm.ujep.cz

Nowadays is issue investigation the notch problems and their influence on component durability. For many manufactured components, we find various types of notches, such as grooves, step and holes. They have a tend to be the place where is concentrated stress, so called the macroscopic stress concentrator. In this area is higher risk of part destruction. Nowadays, there are hypotheses that are based on the assumption that the higher the roughness, the lower the durability. In many cases the designers prescribe unnecessarily high surface quality. It is necessary to maintain adequate quality of the surface, and also necessary that the component has attained a high durability. The paper deals with the influence of machining technology carrying capacity of notched components. As the test material was used steel Fe510 according to EN ISO (11523, according to CSN 42 0002).

\section{References}

[1] BENEDETTI, M., FONTANARI, V. (2009) Influence of Residual Stress Relaxation on Plain and Notch Fatigue of Shot Peened Al-7075-T651. SEM Proceedings, New Mexico, USA

[2] HOLEŠOVSKÝ, F. (2010). Formation and meaning of residual stress of ground surfaces. International Journal of Computational Materials Science and Surface Engineering, No. 1, vol. 3, UK, p. 52-63, ISSN 1753-3465

[3] MALKIN, S. (1989). Grinding Technology - Theory and applications of machining with abrasives, SME, Deaborn, Michigan

[4] XU, Y., ZHANG, T., BAI, Y. (2010). Effect of Grinding Process Parameters on Surface Layer Residual Stress. Advanced Materials Research, vol. 135, Trans Tech, Switzerland

[5] SADELER, R., OZEL A., KAYMAZ, I., Y. TOTIK. (2005). The Effect of Residual Stresses Induced by Prestraining on Fatigue Life of Notched Specimens, JMEP, vol. 14, p. 351, ISSN 1059-9495

[6] HOLESOVSKÝ, F.; NOVAK, M.; LATTNER, M. (2012) Influence of Machining Process on Design Notch Performance. Precision machining VI, Key Engineering Materials - Trans Tech Publications Inc., UK, vol. 496, 217p. ISBN 978-3-03785-297-2

[7] BUMBÁLEK, L. (2001). Importance of Surface Structure for the Function of Machined Surface. Manufacturing Technology, vol. 1, p. $10-15$.

[8] HOLEŠOVSKÝ, F., HRALA, M., ZELENKOVÁ, J. (2006). Ground Surface - Formation and Changes at Dynamical Loading. Manufacturing Engineering, p. 13-17, ISSN 1335-7972

[9] HOLEŠOVSKÝ, F., HRALA, M., ZELENKOVÁ, J. (2007) Properties of Ground Surfaces and Significance of Grinding Process. Proceedings 4th International Congress ICPM , Kielce, Poland, p. 23-27, ISBN 978-83- 8890691-6

[10] MARINESCU D. I., ROWE, W. B., DIMITROV B., INASAKI I. (2004), Tribology of abrasive machining processes, William Andrew, Inc. United States. ISBN: 0-8155-1490-5

[11] RŮŽIČKA, M. (2006). Search for Multiaxial Fatigue Solution. In: Fatigue 2006 - Delegate Manual. Oxford: Elsevier p. 152-153

[12] NOVÁK, M., HIROSHI, K., OHMORI, H. (2013). Differences at the Surface Roughness by the ELID and Grinding Technology. Manufacturing Technology, vol. 13, no. 2, UJEP, Ústí nad Labem p. 210-215 